\title{
UPAYA PENINGKATAN HASIL BELAJAR PKn MELALUI MODEL PEMBELAJARAN PROBLEM BASED LEARNING PADA SISWA KELAS VI SDN GENDONGAN 02 Tego Prasetyo
}

\author{
Sekolah Dasar Negeri Gendongan 02 \\ tego.prasetyo@yahoo.com
}

\begin{abstract}
ABSTRAK
Tujuan dari penelitian ini adalah untuk memperbaiki pembelajaran PKn di SDN 2 Gendongg salama ini hasil belajarnya masih rendah dengan penerapan model pembelajara Problem based Learing (PBL). Penelitian ini merupakan enelitian tindakan kelas yang diterapkan pda siswa kelas VI SDN 2 Gendongan, Salatiga. teknik pengumpulan data menggunakan 2 jenis instrumen berupa tes tertulis dan observasi plus wawancara dengan siswa dan guru kelas. Analisis data menggunakan deskriptif komparatif dengan membandingkan nilai tes yang diperoleh pada kondisi awal dengan nilai tes setelah siklus 1 dan siklus 2. Hasil penelitian menunjukkan model pembelajaran PBL dapat meningkatkan hasil belajar siswa dengan sangat baik. Pada kondisi awal rata-rata nilai hasil tes ulangan harian I dan II adalah 60,12. Penerapan pembelajaran PBL pada siklus I diperoleh ketuntasan kelas sebesar 100\% dengan nilai rata-rata kelas 70 atau meningkat sebanyak 9.88 point. Selanjutnya pada siklus II, nilai rata-rata kelas mencapai 80 atau meningkat sebanyak 19.88 point dari kondisi awal.
\end{abstract}

Kata kunci: problem based learning, pembelajaran PKn, hasil belajar

\section{PENDAHULUAN}

Pendidikan Kewarganegaraan (PKn) merupakan salah satu mata pelajaran yang diberikan mulai dari Sekolah Dasar hingga pada Perguruan Tinggi. PKn berisi mengenai kajian peristiwa, fakta, konsep, dan generalisasi yang berkaitan dengan isu atau masalah social kenegaraan. Pada jenjang Sekolah Dasar mata pelajaran PKn memuat materi Sejarah dan Sistem Ketatanegaraan. Melalui mata pelajaran PKn tersebut, peserta didik diarahkan untuk dapat menjadi warga negara Indonesia yang demokratis dan bertanggungjawab, serta warga dunia yang cinta damai. Gejala yang ada di SD adalah siswa mengalami kesulitan menjawab pertanyaan yang berkaitan dengan penalaran. Bila keadaan ini berlangsung terus maka siswa akan mengalami kesulitan mengaplikasikan pengetahuan yang diperolehnya di kelas dengan kehidupan nyata. Dalam mengkaji seperangkat fakta yang terjadi di lingkungan 
Tego Prasetyo: Upaya peningkatan hasil belajar PKn...

sekitar siswa harus melakukan sesuatu, mengetahui dan memecahkan masalah yang berkaitan dengan masalah-masalah sosial kenegaraan yang dihadapinya. Untuk hal ini bisa didapatkan melalui pembelajaran Problem Based Learning (PBL). Dari data awal yang diperoleh di kelas VI SDN Gendongan 02 pada pembelajaran bidang studi PKn materi sejarah ialah, 1) Rendahnya tingkat penguasaan siswa terhadap materi, yaitu dari beberapa siswa hanya sekitar $20 \%$ siswa yang mencapai tingkat penguasaan materi. 2) Siswa kurang memperhatikan penjelasan guru. Permasalahan ini jelas akan mengakibatkan rendahnya pemahaman siswa terhadap materi yang dipelajari. Berdasarkan fakta tersebut, diperlukan suatu perbaikan pembelajaran yang mengacu pada peningkatan aktivitas dan hasil belajar siswa dengan model pembelajaran Problem Based Learning ( $P B L$ ). Dengan menerapkan model Pembelajaran Problem Based Learning ( $P B L$ ) ini diharapkan siswa mampu menerima dan menerapkan dalam setiap permasalahan yang dihadapi. Peneliti meyakini bahwa dengan model Pembelajaran Problem Based Learning( PBL) ini siswa akan mencapai hasil atau kriteria yang diharapkan oleh guru.

Identifikasi masalah dalam penelitian ini peneliti menyajikan Model Pembelajaran Problem Based Learning ( $P B L$ ) dalam pembelajaran PKn sebagai suatu alternatif dalam pemecahan masalah. sehingga rumusan masalah penelitian ini adalah sebagai berikut “Apakah dengan Model Pembelajaran Problem Based Learning ( PBL) dapat meningkatkan hasil belajar PKn?" Untuk mengetahui upaya peningkatan hasil belajar PKn dengan Model Pembelajaran Problem Based Learning ( PBL ), maka tujuan penelitian ini adalah untuk mengumpulkan bahan masukkan yang dapat digunakan dalam pembelajaran PKn di kelas VI SDN Gendongan 02.

\section{LANDASAN TEORI}

\section{Hasil Belajar}

Hasil belajar adalah prestasi belajar yang dicapai siswa melalui pengukuran maupun penilaian dari hasil proses kegiatan belajar mengajar dan tes. Hasil belajar ini merupakan hasil pengukuran dalam 3 kemampuan yakni kemampuan kognitif, afektif dan psikomotorik, hal ini didukung oleh Benyamin S.Bloom dalam Wardani N.S. (2012:3.23-3.25), kemampuan kognitif terdiri knowledge (pengetahuan, ingatan), comprehension (pemahaman, menjelaskan, meringkas, contoh), application (menerapkan), analysys (menguraikan, menentukan hubungan), sysnthesis (mengorganisasikan, merencanakan, membentuk bangunan baru), evaluation (menilai). Kemampuan afektif terdiri dari receiving (sikap menerima), responding (memberikan respon), valuing (nilai), organization (organisasi), Characterization 
Tego Prasetyo: Upaya peningkatan hasil belajar PKn...

(karakterisasi). Kemampuan psikomotor meliputi initiatory, pre-routine, dan rountinized. Psikomotor juga mencakup keterampilan produktif, teknik, fisik, sosial, manajerial, dan intelektual. Menurut Briggs yang dikutip Taruh (2003:17), hasil belajar adalah seluruh kecakapan dan hasil yang dicapai melalui proses belajar mengajar di sekolah yangdinyatakan dengan angka-angka atau nilai-nilai berdasarkan tes hasil belajar. Menurut Rasyid (2008: 9), hasil belajar adalah kemampuan seseorang dapat dinyatakan dengan angka. Hasil tes belajar siswa, akan memberikangambaran informasi tentang kemampuan dan penguasaan siswa pada suatu materipelajaran yang kemudian dikonversi dalam bentuk angka-angka. Menurut Dimiyati dan Munjiono (2013:200) hasil belajar merupakan proses untuk menentukan nilai belajar siswa melalui kegiatan penilaian atau pengukuran hasil belajar. Berdasarkan pendapat para ahli tersebut hasil belajar adalah besarnya angka yang diperoleh dari aspek, afektif, kognitif dan psikomotorik melalui pembelajaran.

Permendikbud No 23 Tahun 2016 Standar Penilaian Pendidikan menjelaskan bahwa standar penilaian pendidikan adalah kriteria mengenai lingkup, tujuan, manfaat, prinsip, mekanisme, prosedur dan instrument penilaian hasil belajar peserta didik pada pendidikan dasar dan pendidikan menengah. Penilaian adalah proses mengumpulkan dan pengelolaan informasi untuk mengukur pencapaian hasil belajar peserta didik. Ruang lingkup penilaian hasil belajar mencakup 3 ranah yaitu, afektif, kognitif dan psikomotorik yang dilakukan secara berimbang sehingga dapat digunakan sebagai acuan peserta didik terhadap standar kelulusan yang telah ditetapkan. Hasil belajar siswa dapat diketahui dengan melakukan pengukuran. Menurut Wardani N.S. dkk, (2012:4.24) pengukuran diartikan sebagai kegiatan atau upaya yang dilakukan untuk memberikan angka-angka pada suatu gejala atau peristiwa, atau benda. Alat yang digunakan untuk mengukur disebut instrument. Menurut Wardani N.S (2012:144-145), pengelompokkan jenis-jenis tes berdasarkan cara mengerjakan, dapat dibedakan menjadi 3 yakni tes tertulis (berbentuk tes objektif, pilihan ganda, jawaban singkat atau isian, benar salah, dan bentuk menjodohkan dan berbentuk tes uraian); tes lisan dan tes perbuatan. Jenis tes berdasarkan bentuk jawabannya, dapat dibedakan menjadi 3 yakni tes isian ( essay-tyfe); tes jawaban pendek dan tes objektif. Teknik nontes merupakan teknik penilaian atau evaluasi hasil belajar peserta didik yang dilakukan dengan tanpa menguji peserta didik melainkan dilakukan melalui observasi, wawancara, skala, dan portofolio.

\section{Model Pembelajaran Problem Based Learning (PBL)}

Menurut Joyce (dalam Trianto, 2007:5) menyatakan bahwa model pembelajaran adalah sesuatu perencanaan atau suatu pola yang digunakan sebagai pedoman dalam 
Tego Prasetyo: Upaya peningkatan hasil belajar PKn...

merencanakan pembelajaran dikelas atau pembelajaran dalam tutorial dan untuk menentukan perangkat-perangkat pembelajaran termasuk di dalamnya buku-buku, flim, komputer, dll. Jadi dapat di tarik kesimpulan dari peneliti di atas bahwa model pembelajaran adalah suatu perencanaan pembelajaran secara konseptual yang dirancang secara sistematis demi pencapaian tujuan dan berfungsi sebagai pedoman bagi pelaksanaan pembelajaran Problem Based Learning (PBL) adalah kurikulum dan proses pembelajaran. Dalam kurikulumnya, dirancang masalah-masalah yang menuntut siswa mendapat pengetahuan yang penting, membuat mereka mahir dalam memecahkan masalah, dan memiliki strategi belajar sendiri serta memiliki kecakapan berpartisipasi dalam tim. Proses pembelajarannya menggunakan pendekatan yang sistematik untuk memecahkan masalah atau menghadapi tantangan yang nanti diperlukan dalam karir dan kehidupan sehari-hari.

Menurut Riyanto (2009:288) Problem Based Learning (PBL) memfosuskan pada siswa menjadi pembelajaran yang mandiri dan terlibat lansung secara aktif dalam pembelajran kelompok. Model ini membantu siswa untuk mengembangkan berpikir siswa dalam mencari pemecahan masalah melalui pencarian data sehingga diperoleh solusi untuk suatu masalah dengan rasional dan ontentik. Problem Based Learning (PBL) mempunyai perbedaan penting dengan pembelajaran penemuan. Pada pembelajaran penemuan didasarkan pertanyaan-pertanyaan berdasarkan disiplin ilmu dan penyelidikan siswa berlangsung di bawah bimbingan guru terbatas dalam ruang lingkup kelas, sedangkan Problem Based Learning (PBL) dimulai dengan masalah kehidupan nyata yang bermakna dimana siswa mempunyai kesempatan dalam memlilih dan melakukan penyelidikan apapun baik di dalam maupun di luar sekolah sejauh itu diperlukan untuk memecahkan masalah. Problem Based Learning (PBL) merupakan pendekatan yang efektif untuk pengajaran proses berpikir tingka tinggi, pembelajaran ini membantu siswa untuk memproses informasi yang sudah jadi dalam benaknya dan menyusun pengetahuan mereka sendiri tentang dunia sosial dan sekitarnya. Dengan Problem Based Learning (PBL) siswa dilatih menyusun sendiri pengetahuannya, mengembangkan keterampilan memecahkan masalah. Selain itu, dengan pemberian masalah autentik, siswa dapat membentuk makna dari bahan pelajaran melalui proses belajar dan menyimpannya dalam ingatan sehingga sewaktu-waktu dapat digunakan lagi. Jadi Problem Based Learning atau pembelajaran berbasis masalah adalah suatu strategi pembelajaran yang menggunakan masalah dunia nyata sebagai suatu konteks bagi peserta didik untuk belajar tentang cara berpikir kritis dan keterampilan pemecahan masalah, serta untuk memperoleh pengetahuan dan konsep yang esensial dari materi pelajaran. 
Tego Prasetyo: Upaya peningkatan hasil belajar PKn...

\section{Langkah-langkah Model pembelajaran Problem Based Learning}

Problem Based Learning (PBL) akan dapat dijalankan bila pengajar siap dengan segala perangkat yang diperlukan. Pemelajar pun harus sudah memahami prosesnya, dan telah membentuk kelompok-kelompok kecil. Umumnya, setiap kelompok menjalankan proses yang dikenal dengan proses tujuh langkah: 1) Mengklarifikasi istilah dan konsep yang belum jelas. Memastikan setiap anggota memahami berbagai istilah dan konsep yang ada dalam masalah. Langkah pertama ini dapat dikatakan tahap yang membuat setiap peserta berangkat dari cara memandang yang sama atas istilah-istilah atau konsep yang ada dalam masalah. 2 ) Merumuskan masalah. Fenomena yang ada dalam masalah menuntut penjelasan hubungan-hubungan apa yang terjadi di antara fenomena itu. 3) Menganalisis masalah. Anggota mengeluarkan pengetahuan terkait apa yang sudah dimiliki anggota tentang masalah. Terjadi diskusi yang membahas informasi faktual (yang tercantum pada masalah), dan juga informasi yang ada dalam pikiran anggota. Brainstorming (curah gagasan) dilakukan dalam tahap ini. 4) Menata gagasan secara sistematis dan menganalisis. Bagian yang sudah dianalisis dilihat keterkaitannya satu sama lain kemudian dikelompokkan; mana yang paling menunjang, mana yang bertentangan, dan sebagainya. Analisis adalah upaya memilah sesuatu menjadi bagian-bagian yang membentuknya. 5) Memformulasikan tujuan pembelajaran. Kelompok dapat merumuskan tujuan pembelajaran karena kelompok sudah tahu pengetahuan mana yang masih kurang, dan mana yang masih belum jelas. Tujuan pembelajaran akan dikaitkan dengan analisis masalah yang dibuat. 6) Mencari informasi tambahan dari sumber lain. Saat ini kelompok sudah tahu informasi apa yang tidak dimiliki, dan sudah punya tujuan pembelajaran. Kini saatnya mereka harus mencari informasi tambahan itu, dan menemukan kemana hendak dicarinya. 7) Mensistesis (menggabungkan) dan menguji informasi baru dan membuat laporan.

Riyanto (2009:288) mengemukan bahwa langkah-langkah Problem based learning (PBL) ada 5 tahap yaitu: a) Guru mempersiapkan dan melempar masalah kepada siswa. b) Membentuk kelompok kecil, dalam masing-masing kelompok siswa mendiskusikan masalah tersebut dengan memanfaatkan dan merefleksi pengetahuan/keterampilan yang mereka miliki. Siswa juga membuat rumusan masalah dan membuat sebuah pernyataan. c) Siswa mencari informasi dan data yang berhubungan dengan masalah yang sudah dirumuskan. d) Siswa berkumpul dalam kelompok untuk melaporkan data apa yang sudah diperolah dan mendiskusikan dalam kelompok berdasarkan data-data yang diperoleh tersebut. Langkah ini diulang-ulang sampai memperoleh solusi. e) Kegiatan diskusi penutup sebagai kegiatan akhir, apabila proses sudah memperoleh solusi yang tepat. 
Tego Prasetyo: Upaya peningkatan hasil belajar PKn...

\section{Kerangka Berpikir}

Skema kerangka berpikir berikut pada awalnya sebelum penelitian tindakan ini. Guru dalam mengajar belum menerapkan model pembelajaran Problem Based Learning dengan berbagai alasan, misalnya anak malas belajar, tidak memperhatikan guru, tidak mengerjakan PR dan sebagainya, sehingga hasil belajar rendah. Berdasarkan kenyataan yang ada, maka hasil belajar siswa yang diharapkan belum tercapai. Supaya hasil belajar meningkat guru perlu melakukan tindakan .Pada saat mengajar materi PKn tentang menceritakan secara singkat sikap kebersamaan dalam proses perumusan Pancasila sebagai dasar Negara, guru menerapkan model pembelajaran Problem Based Learning. Pada siklus-1 dengan cara menerapkan model pembelajaran Problem Based Learning secara kelompok, tiap kelompok antara 4-5 siswa. Apabila belum meningkat model Problem Based Learning dilakukan secara individual. Dengan dua tindakan ini akan diakhiri kondisi akhir diduga melalui model pembelajaran Problem Based Learning dapat meningkatkan hasil belajar PKn.

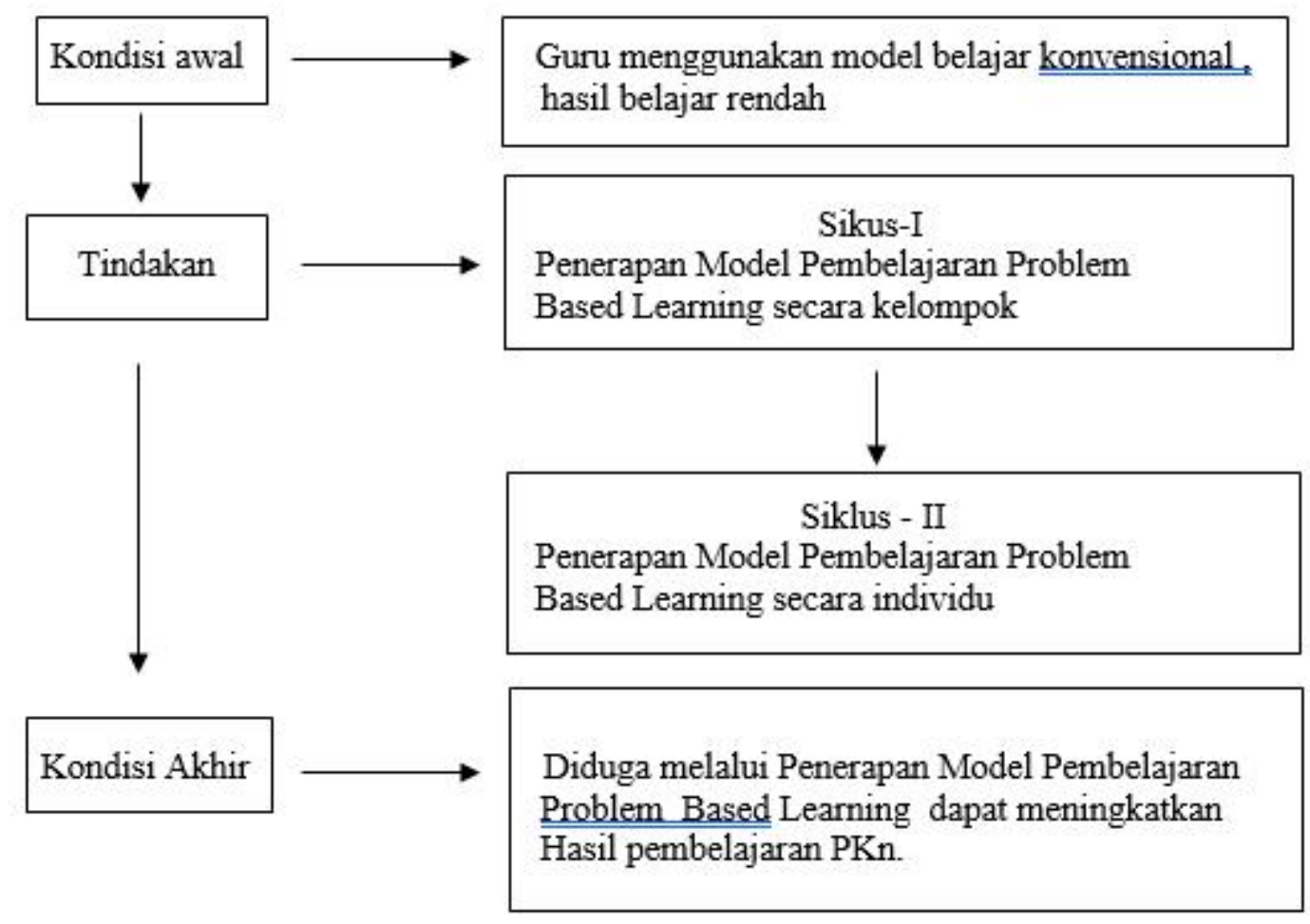

Gambar 1. Kerangka berpikir penelitian 
Tego Prasetyo: Upaya peningkatan hasil belajar PKn...

\section{METODE PENELITIAN}

Jenis penelitian ini adalah Penelitian Tindakan Kelas (PTK) yang merupakan pencermatan terhadap suatu kegiatan pembelajaran dimana guru memunculkan sebuah tindakan yang disusun sehingga nantinya diterapkan pada peserta didik dalam proses pembelajaran kelas ( Rubiyanto 2009 : 108 ). Sample atau subjek penelitian adalah para siswa adalah siswa kelas VI SDN Gendongan 02 Salatiga. Guna memperoleh data peneliti berusaha dengan cara yaitu: (1) Sumber primer yaitu data yang berasal dari subjek langsung siswa kelas VI SDN Gendongan 02 Salatiga. Setiap siklus memerlukan hasil tes ulangan harian satu kali. Dari hasil tersebut dianalisis datanya. (2) Sumber sekunder yaitu data diperoleh dari guru kelas VI. Kemudian data ini direfleksikan pada tiap-tiap siklus atau tindakan.

teknik yang digunakan dalam penelitian ini adalah menggunakan dua teknik yaitu: (a) tes tertulis, dimana setiap siklus diadakan tes tertulis, pada siklus pertama dengan indikator yang sifatnya berorientasi pada pemberian motivasi belajar secara berkelompok, sedangkan pada siklus kedua yang indikatornya bersifat pemberian motivasi belajar secara individual. (b) teknik non tes, yang dilakukan melalui pengamatan dan wawancara dengan siswa dan guru kelas. Data yang diperoleh dari hasil pengamatan akan dicatat dalam lembar pengamatan. Observasi digunakan adalah observasi berstruktur, dimana segala kegiatan peneliti telah menetapkan kerangka kerja yang memuat faktor-faktor yang telah diatur kategorinya. Luas materi observasi telah ditetapkan dan dibatasi dengan tegas. Kebaikannya adalah : 1) Karena data observasi diperoleh langsung dan lebih objektif. 2) Data observasi ini mencakup berbagai aspek kepribadian siswa. Untuk memperoleh data yang akurat, peneliti berusaha membuat soal-soal dan lembar pengamatan. Soal tersebut disesuaikan dengan tujuan pembelajaran yang akan dicapai, sedangkan lembar pengamatan disesuaikan dengan variable yang diamati.

\section{Analisis Data}

Berdasarkan hasil tes tertulis dan wawancara, maka data tersebut dianalisis. Analisis data dalam penelitian ini menggunakan diskriptif komparatif, karena membandingkan nilai tes yang diperoleh pada kondisi awal dengan nilai tes setelah siklus 1 dan siklus 2. Hasil belajar pada kondisi awal diperoleh dari nilai tes harian, nilai tes harian tersebut dijabarkan dalam nilai rata-rata, maksimal dan nilai minima. Hasil belajar siklus 1 diperoleh dari nilai ulangan harian, dengan Kompetensi Dasar adalah” Menghargai nilai-nilai juang dalam proses perumusan Pancasila,sebagai dasar Negara "Dengan indikatornya adalah : 1) Contoh sikap peserta sidang dalam proses perumusan Pancasila, 2) Manfaat sikap kebersamaan, 3) Contoh 
Tego Prasetyo: Upaya peningkatan hasil belajar PKn...

penerapan sikap kebersamaan walaupun beda pendapat, 4) Cara melakasanakan keputusan.Kemudian dibandingkan dengan kondisi awal dan siklus 2 ( dua ) pada siklus 1 ( satu ) pembelajaran dilaksanakan dengan kelompok. Sedangkan siklus 2 ( dua ) hasil belajar diperoleh dari nilai ulangan harian dengan kompetensi dasar sama pada siklus 1, karena Rencana Pelaksanaan Pembelajaran dibuat untuk dua kali pertemuan, hanya yang berbeda pada materi atau indikatornya. Untuk siklus 2 dengan indikator adalah : 1) Contoh penerapan sikap kebersamaan ,2) Cara pelaksanaan keputusan bersama.

Hasil ini kemudian dibandingkan dengan awal dan siklus 1 (satu). Pada siklus 2 (dua) pembelajaran dilaksanakan dengan penugasan individual. Semua hasil belajar siswa merupakan indicator untuk menentukan berhasil atau tidaknya tindakan ini, kemudian dianalisis dan refleksi untuk digunakan sebagai bahan tindakan selanjutnya.

\section{HASIL DAN PEMBAHASAN}

Hasil belajar PKn pada kondisi awal belum maksimal atau masih rendah, hal ini dikarenakan belum menggunakan model pembelajaran yang menarik. Selama ini guru hanya menggunakan model pembelajaran konvensional, padahal saat ini sudah banyak dikembangkan model - model pembelajaran yang diharapkan mampu meningkatkan hasil belajar siswa. Penerapan model pembelajaran Problem Based Learning motivasi diharapkan dapat membantu dalam memecahkan permasalahan yang dihadapi siswa. Minimnya hasil belajar siswa pada kondisi pra-perlakuan dapat dilihat pada Tabel 1.

Tabel.1 Nilai Tes Kondisi Awal

\begin{tabular}{llccc}
\hline No & \multicolumn{1}{c}{ Uraian } & \multicolumn{2}{c}{ Nilai } \\
\cline { 3 - 5 } & Terendah & Tertinggi & Rata-rata \\
\hline $1 . \quad$ & $\begin{array}{l}\text { Ulangan harian I } \\
\text { Indikator: Memberi contoh sikap untuk } \\
\text { mencapai kebersamaan dalam perumusan } \\
\text { pancasila. }\end{array}$ & 29 & 66 & 50,18 \\
\hline 2. & $\begin{array}{l}\text { Ulangan harian II } \\
\text { Indikator: Contoh penerapan sikap } \\
\text { kebersamaan walau beda pendapat.Cara } \\
\text { melaksanakan keputusan bersama }\end{array}$ & 40 & 72 & 61,56 \\
\hline
\end{tabular}

Pada kondisi awal didapati nilai hasil tes ulangan harian I dengan hasil nilai terendah adalah 29 dan nilai tertinggi adalah 66 sedangkan pada ulangan harian II nilai terendah adalah 40 dan nilai tertinggi adalah 72 . Jika dibandingkan dengan nilai rata-rata pada kondisi awal 
Tego Prasetyo: Upaya peningkatan hasil belajar PKn...

adalah 60,12 , berarti telah terjadi peningkatan. Dari kenyataan tersebut pada kondisi awal ini belum menerapkan model pembelajaran Problem Based Leaarning, akibatnya hasil belajar PKn kurang maksimal atau masih rendah, dengan kata lain belum mencapai standar Ketuntasan Belajar yang ditetapkan sekolah.

\section{Hasil belajar setelah penerapan PBL}

Tabel. 2 Keadaan siswa setelah penerapan PBL

\begin{tabular}{ccc}
\hline Pengamatan & \multicolumn{1}{c}{ Siklus-1 } & \multicolumn{1}{c}{ Siklus-2 } \\
\hline Nilai rata-rata & 70 & 80 \\
\% ketuntasan & 100 & 100 \\
Hasil observasi kelas & $\begin{array}{l}\text { PBM dengan telah di } \\
\text { terapkan model } \\
\text { pembelajaran Problem } \\
\text { Based Learning } \\
\text { namun belum semua } \\
\text { siswa tampak aktif }\end{array}$ & $\begin{array}{l}\text { PBM dengan telah di } \\
\text { terapkan model } \\
\text { pembelajaran }\end{array}$ \\
$\begin{array}{l}\text { Problem Based } \\
\text { Learning dengan } \\
\text { semua siswa aktif }\end{array}$ \\
\hline
\end{tabular}

Berdasarkan hasil siklus 1 dengan menerapkan model pembelajaran Problem Based Leaarning dan langkah-langkah yang ditempuh dalam proses belajar mengajar dan hasil pengamatan sebagai berikut:

1. Perencanaan. Peneliti membuat Rencana Pelaksanaan Pembelajaran dengan rincian

Sebagai berikut : (a) Kegiatan awal dengan memberikan apersepsi : Tanya jawab : Siapakah tokoh yang merumuskan Pancasila. (b) Kegiatan inti. Siswa mendengarkan penjelasan guru secara singkat tentang materi pelajaran, mencatat hal-hal penting, mengerjakan tugas bersama-sama dalam kelompok masing masing dan melaporkan hasil kerja kelompoknya selanjutnya mengerjakan tugas dari guru berupa tes

2. Pelaksanaan Tindakan. Tindakan yang dilaksanakan oleh peneliti sesuai dengan perencanaan sebelumnya yaitu : a) Adanya kegiatan awal yang dimulai dengan apersepsi guna membangkitkan motivasi siswa.b) Kegiatan inti menerapkan model pembelajaran Problem Based Leaarning agar siswa lebih kreatif dalam mencari jawaban, c) Kegiatan akhir hanya menyimpulkan materi ajar dan memberi tugas tambahan atau PR.

\section{Hasil Pengamatan}

Hasil pengamatan pada siklus 1dapat dilihat keaktifan siswa, kreatifitas yang dilakukan siswa dalam mencari jawaban. Hasilnya dapat dilihat dalam Tabel 2. Pada siklus 1 telah di terapkan model pembelajaran Problem Based Learning, dapat meningkatkan hasil belajar 
Tego Prasetyo: Upaya peningkatan hasil belajar PKn...

PKn tentang Proses Perumusan Pancasila sebagai Dasar Negara. Namun, pada siklus 1 masih ada siswa yang belum mengajukan pertanyaan, menjawab pertanyaan guru, aktif kerja dalam kelompok dan bersedia menerima koreksi dari temannya, ini menunjukkan belum ada peningkatan yang signifikan.

\section{Refleksi}

Pada tindakan siklus-1 ini dari nilai rata-rata hasil belajar siswa meningkat dari kondisi awal 60,12 menjadi 70. Sehingga nilai rata-rata pada siklus-1 ini naik menjadi 9,88 dan ketuntasan belajar sudah sesuai dengan Standar Ketuntasan Belajar Minimal yang ditetapkan sekolah, bahkan melebihi target yaitu 70 .

Hasil penelitian pada siklus-2 dengan langkah-langkah dalam proses belajar mengajar mengajar serta hasil pengamatan sebagai berikut:

1. Perencanaan. Peneliti membuat Perencanaan Pelaksanaan Pembelajaran dengan rincian sebagai berikut: (a) Kegiatan Awal : Apersepsi yang diawali dengan tanya jawab guna memotivasi siswa dalam menerima pelajaran. Apakah manfaat sikap kebersamaan? (b) Kegiatan Inti: Siswa mendengarkan penjelasan guru secara singkat, mencatat materi yang dianggap penting, selanjutnya siswa mengerjakan tugas individual, dan melaporkan secara singkat, mencatat materi yang dianggap penting, selanjutnya siswa mengerjakan tugas individu dan melaporkan secara tertulis kemudian mengerjakan lembar tes yang disediakan.

2. Pelaksanaan Tindakan. Tindakan yang dilaksanakan oleh peneliti sesuai dengan perencanaan sebelumnya yaitu : a) Adanya apersepsi guna menghubungkan materi pelajaran yang lalu dengna yang sekarang,dan membangkit semangat siswa untuk belajar. b) Kegiatan inti telah di terapkan model pembelajaran Problem Based Learning agar aktif belajar dan mencari tahu jawaban yang akan dicari. c) Kegiatan akhir siswa menyimpulkan materi pelajaran dan mencatat tugas tambahan dari guru atau PR

3. Hasil Pengamatan. Hasil dari pengamatan berupa hasil belajar siswa dalam tindakan pada siklus-2, hasilnya dapat dilihat dalamTabel 2.

Dari hasil pengamatan tersebut pada siklus-2 masih ada siswa yang belum mau mengajukan pertanyaaan dan menjawab pertanyaan guru, tapi sudah ada peningkatan. Hal ini ditujukan bahwa siswa semua aktif dan ada motivasi untuk menyelesaikan tugas dengan baik dan cermat.

\section{Refleksi}

Pada tindakan ini atau siklus-2 ini telah di terapkan model pembelajaran Problem Based Learning, pembelajaran maka tugas yang diberikan pula secara individual, sehingga hasil yang dicapai dapat dibandingkan dengan kondisi awal nilai rata-rata naik, dari nilai rata- 
Tego Prasetyo: Upaya peningkatan hasil belajar PKn...

rata pada siklus-1 70 sehingga pada siklus-2 nilai rata-rata 80 . Jadi nilai rata-rata pada siklus-2 naik menjadi 10 dan semua siswa dinyatakan tuntas belajar,nilai dapat dilihat pada tabel berikut ini.

Hasil belajar siswa pada kondisi awal bila dibandingkan dengan hasil belajar pada siklus-1 mengalami kenaikan sebesar 9,88, sedangkan hasil belajar pada siklus-1 bila dibandingkan dengan hasil belajar siklus-2 ada peningkatan sebesar 10, hal ini menunjukkan bahwa pembelajaran dengan telah diterapkan model pembelajaran Problem Based Learning dapat meningkatkan hasil belajar siswa pada pembelajaran PKn. Pada umumnya melalui pembelajaran dengan telah di terapkan model pembelajaran Problem Based Learning dapat mencegah terjadinya kebosanan para siswa dan bisa membangkitkan minat siswa untuk belajar aktif dan respon dari siswa sangat positif dan bersemangat untuk belajar, dengan demikian dapat dikatakan ada peningkatan hasil belajar siswa.

\section{KESIMPULAN}

Dari penelitian diperoleh kesimpulan bahwa penerapan PBL apat meningkatkan hasil belajar siswa SDN 2 Gendongan khususnya pada pelajaran PKn. Selanjutnya, disarankan kepada guru untuk menggunakan model pembelajaran yang menarik, salah satunya yaitu dengan model problem based learning.

\section{DAFTAR PUSTAKA}

Sudjana.N, 2001, Penilaian Hasil Proses Belajar Mengajar, Bandung : PT Remaja Rosdakarya.

Basuki.W.,2003, Penelitian Tindakan Kelas. Jakarta : Departemen Pendidikan Nasional Direktorat Pendidikan Dasar dan menengah Direktorat Tenaga Kependidikan ,2007, Panduan Penulisan Pilihan Ganda , Jakarta : Departemen Pendidikan Nasional.

Trianto, 2007. Model-model Pembelajaran Inovatif Berorientasi Konstrutivistik. Jakarta: Prestasi Pustaka

M. Taufiq Amir,2009. Inovasi Pendidikan Melalui Problem Based Learning. Jakarta: Media Group

Wiriaatmaja.R,2012, Metode Penelitian Tindakan Kelas, Bandung : PT.Remaja Rosdakarya. Slameto, 2013. Belajar dan Faktor-faktor yang Mempengaruhinya. Jakarta: Rineka Cipta. 
Tego Prasetyo: Upaya peningkatan hasil belajar PKn...

Noviasari, Sari, 2015.Peningkatan Hasil Belajar Ilmu Pengetahuan Sosial Melalui Model Problem Based Learning (PBL) Pada Siswa Kelas IV SDN Tegalrejo 3 Yogyakarta. Jurnal UNY 